\title{
No Harm No Foul Behavior and Consumption Motivation Among Indonesian Students
}

\author{
Juneman Abraham and Ammeta Firly Maulida \\ Department of Psychology \\ Bina Nusantara University
}

\begin{abstract}
Large scale corruption could start from everyday unethical daily behavior. Due to its "everyday" nature, the effects of such behavior often go unnoticed. This research examines the no harm no foul behavior (NHNF) as a behavior that is located in the "gray area" but can be perceived as unethical by some people. The psychological predictors of the behavior will be investigated, i.e. utilitarian and hedonic motivation in a world of consumption. Participants were late adolescent students recruited through convenience sampling technique in the Greater Area of Jakarta, the Capital of Indonesia (148 males, 72 females; $M_{\text {age }}$ $=20.055$ years old, $S D_{\text {age }}=1.181$ years). It was found that utilitarian motivation can predict the evaluation of NHNF as an unethical behavior in a positive direction while hedonic motivation was not found to be able to predict it. Suggestions to improve the NHNF measurement and implications also issues to be considered when applying the results of the study will be discussed at the end of this article.
\end{abstract}

Keywords: ethical behavior, utilitarianism, hedonism, consumption, no harm no foul

Korupsi berskala besar dapat berawal dari tingkah laku sehari-hari yang mengarah pada ketidaketisan. Oleh karena bersifat "sehari-hari", maka dampaknya terhadap moralitas seseorang seringkali tidak disadari. Penelitian ini mengangkat perilaku tan-mudarat tanburuk yang merupakan tingkah laku yang berada dalam wilayah "abu-abu" namun dipersepsikan sebagai tidak etis oleh sebagian orang, serta menyelidiki prediktor psikologisnya, yakni motivasi utilitarian dan motivasi hedonik dalam dunia konsumsi. Partisipan penelitian ini adalah mahasiswa, pada tahap perkembangan remaja akhir, yang direkrut melalui teknik penyampelan convenience di Jakarta, ibu kota Indonesia, dan sekitarnya, yakni Bogor, Depok, Tangerang, dan Bekasi (148 laki-laki, 72 perempuan; $M_{\text {usia }}$ $=20.055$ tahun, $S D_{\text {usia }}=1.181$ tahun). Ditemukan bahwa motivasi utilitarian mampu memprediksikan evaluasi tentang ketidaketisan perilaku tan-mudarat tan-buruk dalam arah positif, dan motivasi hedonik tidak mampu memprediksikannya. Saran-saran tentang perbaikan alat ukur perilaku tan-mudarat tan-buruk serta implikasi dan hal-hal yang perlu dipertimbangkan dalam penerapan hasil penelitian ini dikemukakan pada bagian akhir dari artikel ini.

Kata kunci: perilaku etis, utilitarianisme, hedonisme, konsumsi, tan-mudarat tan-buruk

No harm no foul behavior (NHNF) is a questionable behavior committed by a consumer in which the actor perceives no direct harm will be suffered by anyone receiving the consequence of the action, and, therefore, NHNF cannot be seen as unethical (Egan \& Taylor, 2010; Muncy \& Vitell, 1992; Vitell \&

Correspondence concerning this article should be addressed to Juneman Abraham and Ammeta F. Maulida, Department of Psychology, Faculty of Humanities, Bina Nusantara University, Jl. Kemanggisan Ilir III no. 45, Palmerah, DKI Jakarta 11480. E-mail: juneman@binus.ac.id; ammetaf@ gmail.com
Muncy, 2005), "although these actions can be perceived to be unethical by some from a deontological position (however, not all individuals may find these actions to be unethical)" (Chowdhury \& Fernando, 2013).

An example of NHNF is recording music through radio broadcast for personal enjoyment (instead of buying the album). Other examples of NHNF may cover: (1) Tasting grapes in a supermarket and not buying any; (2) Using computer software or games that you did not buy; (3) Recording an album instead of buying it; (4) Spending over an hour trying 
on different dresses and not purchasing any; (5) Taping a movie off the television; (6) Returning merchandise after trying it and not liking; it is true to consider it as NHNF in Indonesia where this present research was conducted; however, this action might be perfectly acceptable in other countries or cultures (Rawwas, 1996; Vitell, Lumpkin, \& Rawwas, 1991); using cable black boxes that descramble the cable signal, allowing non-paying viewers to view cable (Martin \& Prince, 2009); (7) Taking advantage by using somebody's membership number (Huang, Lu, You, \& Yen, 2012); (8) Downloading music from the internet instead of buying it; and (9) Buying counterfeit goods instead of buying the original manufacturers' brands (Vitell, Singh, \& Paolillo, 2007).

In accordance with its definition, the main psychological driving factor is individual's cognition that actively rationalizes or neutralizes the behavior as victimless or costless (because the loss for others is seen by the individual as insignificant, such as taking home soap, shampoo, sandal, laundry bag or other souvenirs from a hotel room), such that the individual denies to be responsible or does not feel guilty (Egan \& Taylor, 2010). Here, the psychological mechanism is cognitive bias, where a controversial or ethically debatable behavior will be seen as more unethical when it resulted in more negative consequences (Berg-Cross, 1975; Gino, Moore, \& Bazerman, 2009). In NHNF, there appears to be no negative consequence or it could even be seen as having positive consequence to others (indeed it increases also the actor's wellbeing) when seen through the teleological perspective (Chowdhury \& Fernando, 2013), for example recording music concerts and sharing it through an online file/video sharing activities for others who cannot watch it (despite really wanting to watch it).

Gino et al. (2009) stated that such "outcome bias" has ignored the rational principle to a point where it affects moral decision making. The evaluation of morality is no longer determined by the true ethical quality or weight of the behavior, but by results or consequences alone. In consumer psychology, NHNF affects the morality of the consumer, where considerations about purchases (and subsequent purchases) and the evaluation towards a business institution are very much affected by intuitive drives based on the outcomes they received. No matter how ethical the desire, effort, and behavior of a company, such action will be looked down by the consumer or the client if they have a bad experience with the product or service being offer- ed. On the other hand, no matter how unethical the act of the company if it is "lucky" (did not result in a noticeable loss on the side of clients/consumers or even benefit them), the behavior will be seen as ethical. This showed that NHNF could influence consumers to inappropriately reward or punish the performance of individuals, groups, or institutions. This is clearly dangerous and can "confound judgement" in a meritocratic system in the business or everyday life while rationalizing the saying "the end justifies the means" (e.g. Rachel, 2004) even though the means are unethical.

Experimental research done by Gino, Shu, and Bazerman (2010) further noted that an unethical act is considered increasingly blameless if victims of such act become increasingly difficult to identify. Applying this thesis, it can be stated that even though NHNF is perceived as victimizing behavior, the victims are considered more as "statistical victim" (Gino et al., 2010)_-“a large, ambiguouslydefined entity" (Kandrack \& Lundberg, 2013), such as hundreds of thousands of productive citizens, talented contributors to science, commerce, and art (Trachtman, 1985) - and thus the actor will commit NHNF relaxedly. One possible explanation for this phenomenon is the presence of social-affective distance (less sympathy) (Loewenstein, Small, \& Strnad, 2006) between the evaluator and the so-called "nameless" victim of NHNF.

Based on the reality that the actor of NHNF believes that NHNF has little to no negative consequence as well as little to no (identifiable) victims, he/she may feel morally legitimized to continue the "blameless" act. The actor is unaware that such legitimization will "gnaw" on their morality, where they experience "moral disengagement" (due to weakening moral identity; Chowdhury \& Fernando, 2014), and can result in worse unethical behavior (cumulative effect) such as corruption.

Some political corruption has been assumed by some groups of people as having characteristics of NHNF such as "no one is seemingly harmed", trivial, justified, or even useful to smooth out recruitment, assimilation, and political distribution as well as its apparatus, and dealing with bureaucracy (DeLeon, 2015). This is indicated from a statement regarding corruption saying that it is "the oil of development" uttered by the Vice Chairman of the Indonesian House of Representatives, Fadli Zon (as cited in Khafifah, 2015). Such statement could be analyzed from the paradigm of moral consistency, which will be described in the following section. 
The phenomenon of moral consistency described by Shu, Gino, and Bazerman (2011) is when an individual routinely performs dishonest behavior without feeling guilty. One dishonest behavior brings about other similar behaviors. The construct that can explain this process is moral disengagement (Bandura, 1986, 1990). After doing an unethical behavior, a person might distance himself/ herself from his/her own ethical values. The psychological mechanism occurring here is a cognitive mechanism that deactivates self-regulation, such that unethical behavior becomes acceptable or personally valid. If an individual wants to become moral creatures, and his/her action opposes the goals (such as being involved in NHNF), the person will experience distress caused by cognitive dissonance. Individuals then try to alleviate the dissonance by changing their attitude, especially if the behavior is internally attributed (that the immoral behavior is personally chosen by him/her). In other words, individuals reduce the dissonance by changing their attachment to the moral standards.

Some forms of moral disengagement are: (1) projection, stating that the immoral behavior was done instead for a moral goal (e.g., NHNF can help others too or can benefit the nobler interest); (2) explaining the cause of the immoral behavior with external attri-butions; (3) distorting the consequence of the immoral behavior; and (4) dehumanizing the victims of the immoral behavior. Psychologically, such acts of moral disengagement cause the immoral behavior to be seen as "less immoral" because the individual re-code the meaning of such acts on themselves. Ethical boundaries thus become more flexible. People become more tolerant towards future unethical behavior. This is also supported by another phenomenon such as motivated forgetting, i.e. strategies used by people to selectively forget moral rules after deciding to commit unethical behavior.

Such logic brings us to the urgency of the present study. It is important to understand which variables can predict NHNF. In addition, this research can be used as a baseline to create strategies among employers or companies to prevent NHNF in their consumers (or to maintain or raise consumer ethics) by targeting the abstract, basic psychological variables such as motivation. In this research, motivation is defined as psychological strength (goal orientation, intentionalities, energizing processes, and perseverance) that drives people to have commitment to act, to do the act, and to be responsible for the act, based on a higher level concept guiding the behavior across different contexts and situations, i.e., values (Agerström \& Björklund, 2013; Oser, 2013). Motivation can explain why knowledge is not enough to make someone committing an act.

Previous studies investigated variables that are associated with or are even predictive of NHNF. NHNF is associated with gender (men are more likely to do it), at least in the United States (Callen \& Ownbey, 2003), although, unfortunately, there was no explanation for the finding. It is also associated with actual self-concept (positive actual self-concept rejects NHNF due to developed conscience), self-monitoring (higher self-monitoring rejects NHNF because it is easier to adopt universal ethics from the social environment), and moral development level (Kavak, Gürel, \& Eryigit, 2009); money ethic (love of money has a positive correlation with NHNF) (Vitell et al., 2007), social status anxiety and vertical collectivism (Chiou \& Pan, 2007), attitudes toward salespeople and relationship quality with seller (Liu, Zeng, \& Su, 2009; $\mathrm{Lu} \& \mathrm{Lu}, 2009$ ), and Machiavellianism (Arli, Tjiptono, \& Winit, 2015).

Generation X individuals born between the 1960 and 1982 did not show high consumer ethical values in NHNF dimensions, at least in the United States (Martin \& Prince, 2009). This might be because a majority of Gen X individuals are highly educated, have a managerial position in professional offices, and are the "evolving generation" that need status and as many personal achievements as possible. NHNF is therefore not seen as a bad behavior as long as the act goes unnoticed by the public, by the "victim", or if they are not caught in the act of doing it, in supporting their high even ambitious aspirations. In short, NHNF is permissible because there seems to be no direct victim of the act. NHNF is considered analogous to deception in advertising that has occurred in a massive and prolonged manner in the society that has indirect effects (if it indeed really victimizes). Other research showed that external locus of control (LOC) and risk-taking propensity can positively predict NHNF in positive directions (Ding, Chang, \& Liu, 2009). NHNF is seen as an ambiguous behavior. Regarding this fact, those with external LOC can attribute the responsibility for the results of NHNF to others or the situation, making them more susceptible to perceiving NHNF as an ethical behavior for themselves. Individuals with high risk-taking propensity have lower uncertainty avoidance, and are more relaxed regarding following ethical regulations and 
principles, and are therefore less sensitive to the lack of ethics in NHNF.

Huang et al. (2012) studied 284 Chinese consumers who have high relativism and low idealism (in terms of ethical ideology compared to Westerners). They found that the more idealistic a consumer is (basing ethical evaluations on universal ethical principles), the more likely NHNF will be rejected. In contrast, high relativists (basing ethical evaluations on the situation, such as whether a behavior is publicly observed or is done in private) are more likely to initiate NHNF. Huang et al. (2012) also found that, in contrast to Callen and Ownbey's (2003) study in the US, young people in China (less than 26 years of age) are instead more ethical (less endorsing of NHNF). This finding is linked to religious and cultural experience, where younger Chinese people (compared to their elders) are more religious and also lacked experiencing Cultural Revolution.

The study by Steenhaut and van Kenhove (2006a) on Belgians found that: (1) personal values of resultant conservation (attachment to tradition, security, and conformity) has a direct positive prediction towards the evaluation of NHNF as unethical, and indirectly predicts it through mediating variable of idealism ethical ideology; and (2) higher personal values of resultant self-enhancement (attachment to achievement and power) is related to lower idealism ethical ideology, and lower evaluation of NHNF as unethical behavior. Such ethical belief can strengthen the intention to perform unethical behavior through decreased anticipated guilt (Steenhaut \& van Kenhove, 2006b). In accordance with Huang et al.'s (2012) research, this finding highlights the central role of idealism in buffering or suppressing the tendency to perform NHNF behavior.

As seen previously, research on NHNF revolves around ideology, personality traits, and social relationship aspects. To the best of the author's knowledge, past research has yet to examine motivation as a predictor, in particular, hedonic and utilitarian motivation. The present research aims to focus on this two motivation based on the following arguments.

In consumer psychology, the utilitarian motive stresses efficiency, function, usefulness, performance outcome, instrumental action, effectiveness, goal achievement, and minimum effort; while hedonic motivation focuses on enjoyment, fun, adventure, entertainment, excitement, play, experience, and pleasure (Childers, Carr, Peck, \& Carson, 2001; Palazon \& Delgado-Ballester, 2013). Indivi- duals with utilitarian motivation will judge a moral act based on the result or benefit intended for oneself and, more importantly, as many people that can potentially be affected by the behavior of the actor while minimizing negative consequences (Bertens, 2001; Magnis-Suseno, 1987). Individuals with hedonic motivation judges a moral act based on the amount of pleasure acquired for and pain avoided from oneself (Bertens, 2001; Magnis-Suseno, 1987).

Utilitarian motivation in the consumer world encourages people to prioritize deliberative choices for utility maximization, and deliberative choices are capable of breaking ineffective, inefficient habits from the individual, avoiding short-term temptations (Jonsson, 2011), forming virtues that bring people to "eudaimonia (happiness based on the full flowering of one's potential)", as well as self-transcendence. This is because only through exceeding their own self can an individual achieve function, utility, and other things that are more extensive than their own selves (Jonsson, 2011).

When a utilitarian person has an intrinsically purposeful life, are capable of accepting themselves and mastering their environment (including the shopping or consumption environments), able to selfregulate their autonomy, and stresses functionality (instead of prioritizing pleasure) of things or objects in their effort to contribute towards the growth of self and others (not to impress others), these choices will define them. This formed identity indeed contains a feature of being sensitive towards unethical behavior (Jonsson, 2011). From this description, it can be hypothesized that (H1) "Higher utilitarian motivation will be predictively correlated with higher evaluation of how unethical NHNF is" (see Figure 1).

Hedonic motivation is very closely related to maximizing pleasure and self-satisfaction. In their efforts to maximize it, hedonistic people will perform self-regulation (Higgins, 1997). Empirical research by de Bock and van Kenhove (2010) found that promotion-focused self-regulation-stressing on expectation (for example going on an adventure) and the pursuit of the expectation, as well as the need for nurturanceincreases the probability of being tolerant towards NHNF. This is due to the disposition of such hedonic individuals enables them to be more open to changes, face new experiences, opportunities, and new stimulations, thus becoming more susceptible to ignoring normative expectations. If such reality is simplified, then it can be hypothesized that (H2) "Higher hedonic motivation will be predictively correlated with lower evaluation of how unethical NHNF is." 


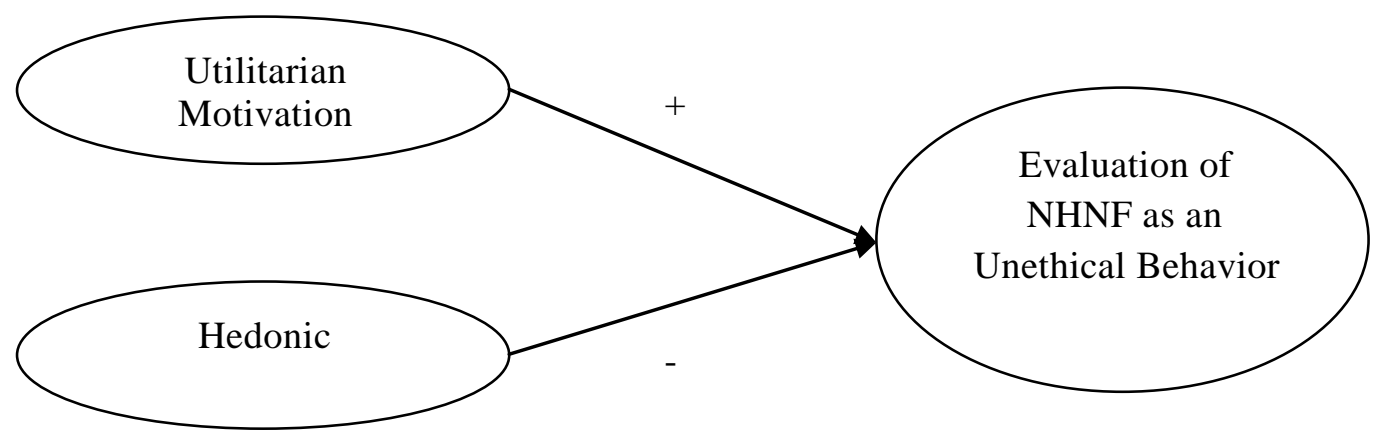

Figure 1. Hypothetical model.

Note. (+) Positive Predictive Correlation; (-) Negative Predictive Correlation

\section{Method}

\section{Participants and Design}

Participants in this study were 220 adolescents aged 15-22 years old, including high school students (SMA Negeri 78, SMA Negeri 85, SMA Islam AlAzhar Pusat, and others) and university students (Bina Nusantara University, Mercu Buana University, Budi Luhur University, and others) up to their 6th semester, recruited through convenience sampling technique in the Greater Area of Jakarta, the Capital of Indonesia (148 males, 72 females; $M_{\text {age }}=20.055$ years old, $S D_{\text {age }}$ $=1.181$ years). This particular sample was chosen because adolescents are thought to be still in the learning process of taking responsibility amid their tendency to rationalize their actions (Workplace Bullying Institute, 2012), making them more vulnerable to committing NHNF. In addition, by understanding predictors of NHNF in the early stages of human development, moral education can be done more effectively (compared to other age groups) due to their ability to be better coached and educated. Recruitment of participants is done with two main methods, which is by approaching potential participants, face to face, in a number of universities and schools in DKI Jakarta and its surroundings, as well as through an online questionnaire (using Google Docs).

Measurement testing was done towards 63 adolescents other than the participants of the field research, who possessed similar characteristics to the participants.

The study used a predictive correlational design, using multiple linear regression data analysis. The predictor variables are utilitarian motivation and hedonic motivation. The criterion variable is an evaluation of NHNF unethicality.

\section{Materials and Procedures}

The scale measuring evaluation towards NHNF is adapted from Vitell and Muncy (as cited in Chowdhury $\&$ Fernando, 2014). It originally consisted of five items, which are: (1) 'Burning' a CD rather than buying it; (2) Returning merchandise after buying it and not liking it; (3) Recording a movie off the television; (4) Spending over an hour trying on clothing and not buying anything; and (5) Installing software on your computer without buying it. The author added 10 items, which are: (1) Making a video recording of a live concert and sharing it to others; (2) Using wi-fi facilities in a convenience store, coffee shop, or a cafe without actually purchasing anything; (3) Tasting sample cakes more than three times without ever intending to buy them; (4) Using makeup testers (e.g., nail polish, lipstick, perfume, powders) without buying anything; (5) Eating more than one fruit tester without buying; (6) Purchasing counterfeit products instead of original ones; (7) Downloading music from the internet without buying the original; (8) Using swimming pool facilities in apartments without own membership; (9) Creating a selfie with an item that is not owned and giving an impression as if the item is owned; and (10) Checking in social media such as Path, Facebook, and others to make it seem as if they are visiting prestigious places when in reality they are not. These ten additional items are the result of observations towards the behavior of adolescents, including direct observation from the immediate environment of the author, and in-direct observation through online texts in social media.

The response options in this measurement scale are: "Very uncertain that the act is morally wrong" 
(score 1), "Uncertain that the act is morally wrong" (score 2), "Somewhat uncertain that the act is morally wrong" (score 3), "Somewhat certain that the act is morally wrong" (score 4), "Certain that the act is morally wrong" (score 5), and "Very certain that the act is morally wrong" (score 6).

Tests of validity and reliability showed that this measurement is reliable with an internal consistency index of more than .6 (Cronbach's Alpha $=.907)$, and the items are valid with corrected item-total correlations of more than .25 (ranging from .289 to .834) after deleting an item, which was "Downloading music from the internet without buying the original."

The measurements of utilitarian and hedonic motivation were adapted from Kim (2006). Hedonic motivation scale consisted of six dimensions with three items for each dimension, which are: (1) Adventure shopping, with an example item: "To me, shopping is an adventure"; (2) Gratification shopping, with an example item: "When I'm in a down mood, I go shopping to make me feel better"; (3) Role shopping, with an example item: "I like shopping for others because when they feel good I feel good"; (4) Value shopping, with an example item: "I enjoy hunting for bargains when I shop"; (5) Social shopping, with an example item: "Shopping with others is a bonding experience"; and (6) Idea shopping, with an example item: "I go shopping to see what new products are available". Utilitarian motivation scale consisted of two dimensions, which are: (1) Achievement (four items), with an example item: "I like to feel smart about my shopping trip", "On a particular shopping trip, it is important to find items I am looking for"; and (2) Efficiency (two items), with an example item: "It is disappointing when I have to go to multiple stores to complete my shopping".

The response options for those measurements range from "Strongly Disagree" (score 1) to "Strongly Agree" (score 6).

Tests of validity and reliability on the utilitarian motivation scale supported its reliability, with an internal consistency index of more than .6 (Cronbach's Alpha $=.746)$, and the items are valid with corrected item-total correlations of more than .25 (ranging from .297 to .607). No items were deleted.

Tests of validity and reliability on the hedonic motivation scale also supported its reliability, with an internal consistency index of more than .6 (Cronbach's Alpha $=.932$ ), and the items are valid with corrected item-total correlations of more than .25 (ranging from .383 to .779). None of the items were deleted.

\section{Results}

The following is a description of the participants: A majority of participants lived in South Jakarta (33.03\%), Tangerang (25.89\%), West Jakarta (21.43\%), East Jakarta $(6.25 \%)$, and Bekasi $(4.46 \%)$. The rest live in Depok, Bogor, North Jakarta, and Central Jakarta. The majority of participants were university students studying communication science (30.36\%), economics (14.28\%), psychology (12.9\%), information system $(8.49 \%)$, engineering science $(6.26 \%)$, and information technology (3.12\%); the rest are currently enrolled in other study programs (law, social and political science, medicine, mathematics and natural sciences, and others). There were also high school students from the Natural Sciences $(3.12 \%)$ and Social Sciences $(2.68 \%)$ program. The majority of participants were Javanese $(42.46 \%)$, Minangnese (17.35\%), Betawinese (11.88\%), Chinese-Indonesian $(7.76 \%)$, Sundanese $(6.85 \%)$ and Bataknese (5.48\%); the rest had ethnic background of Makassar, Maluku, Manado, Ambon, Bali, Bangka Belitung, Papua, and mixed races. Monthly pocket money of participants were from one to two million rupiahs (50\% of participants), less than one million rupiahs $(20.09 \%$ of participants), more than three million rupiahs (18.75\% of participants), and more than two to three million rupiahs $(11.16 \%$ of participants). The total amount of monthly spending of the participants was as follows: One to two million rupiahs $(51.35 \%)$, less than one million rupiahs (19.19\%), more than three million rupiahs $(16.52 \%)$, and more than two to three million rupiahs (12.94\%).

The aim of this study is to investigate whether utilitarian or hedonic consumption motivations are

Table 1

Multiple Linear Regression Analysis Predicting Evaluation of Unethicality of NHNF $(N=220)$

\begin{tabular}{lrrrrc}
\hline Predictor & $B$ & $S E$ B & $B$ & $t$ & $p$ \\
\hline Hedonic motivation & -.027 & .072 & -.028 & -0.378 & .706 \\
Utilitarian motivation & .608 & .219 & .205 & 2.775 & .006 \\
\hline
\end{tabular}

Note. $S E=$ Standard Error 
capable of predicting the evaluation of unethicality of NHNF on adolescents in the Greater Jakarta Area.

The result of multiple linear regression assumption tests showed normal data distribution, also indicating that the data were free from multicollinearity between predictor variables $(V I F<10$, Tolerance $>.1$ ) and heteroscedasticity (the scatterplot did not show a specific pattern and was spread below and above 0 ).

Multiple linear regression analysis results showed that, simultaneously, utilitarian and hedonic motivation can predict evaluation towards the unethicality of NHNF; $F(2,217)=4.226, p=.016, R^{2}=.038$.

Specifically, regarding the main effects, utilitarian motivation can positively predict belief towards immorality/unethicality of NHNF $(\beta=.205, p<.05)$. That is, higher utilitarian motivation contributes to higher endorsement towards the unethicality of NHNF (see Table 1). H1 was supporting by the empirical data.

However, hedonic motivation was not found able to predict the judgment regarding immorality/unethicality of NHNF $(\beta=-.028, p>.05)$. Thus, H2 was not supported by the empirical data.

\section{Discussion}

The current study found that hedonic motivation was not predictive of endorsement towards NHNF unethicality. This may be due to the possibility that hedonic motivation can support and not support NHNF. Dijkstra, Kretschmer, Lindenberg, and Veenstra (2015) found that, in adolescents, hedonic motivation (in pursuing instant gratification) can be functional as a situational motivational contributor for popular adolescents. In this case, their popularity comes from their deviance towards norms created by adults, which usually is manifested through risktaking behavior. Some NHNFs in the questionnaire of the current study are risky behavior, such as using pirated software, downloading illegal music, and purchasing counterfeit items. Hedonic motivation encourages people to prioritize their own needs over everything else. This is in line with cognitive rationalization, a particular defense mechanism underlying NHNF (as explained in the Introduction). In other words, for the adolescents, hedonic motivation endorses the NHNH as an ethical behavior.

However, hedonic motivation can also be seen as an effort to "strive for the "good life" (Adomaviciute, 2013); this opinion also revolved as a discourse in the society. For example, Sidgwick (1981) stated the two types of hedonism: ethical hedonism and egoistic hedonism. Thus, the specific type of hedonic motivation highlighted in the current study does not encompass all forms of hedonic motivation.

Other dynamics of hedonic motivation exist within individuals, and one of them is ethical hedonism. Interestingly, ethical hedonism may actually encourage ethical behavior (i.e., avoiding/rejecting NHNF). This was found to originate from the awareness that ethical behavior can increase selfrespect, which in turn creates a sense of gratification within the individual (Szmigin \& Carrigan, as cited in Adomaviciute, 2013). As can be seen in the Materials and Procedures section earlier, one dimension of hedonic motivation is gratification, where shopping was used as a means for an individual to feel better about himself/herself. Those who commit NHNF may be aware that they are behaving unethically even in the absence of immediate observers, and this could reduce their sense of self-respect (Graf, 1971; Jennifer, 2014), which resulted in more negative feelings (not gratified) towards themselves.

In addition, Magnis-Suseno (1987) stated that:

"However to correctly evaluate hedonism, we need to note that a majority of hedonism philosophers did not make a suggestion to follow blindly our desires, but they also encourage us that in satisfying the needs generating pleasure, we should be responsible, balanced, and can always control the self. For example, a person who truly wants to achieve as much pleasure from eating and drinking should not consume excessively; with a little bit of self-control, he or she will have a much better pleasure when consuming food and beverages" ( $p$. 114).

In accordance with the statement above, a hedonistic person can instead utilize hedonism as an ethical standard for performing a certain behavior, leading to increased self-control. In other words, hedonic motivation can also endorse the NHNH as an unethical behavior.

NHNF done routinely on a moderate intensity may indeed result in gratification (fulfilling hedonic motivation), such as physical pleasure (trying tester products), psychological pleasure (enjoying increased social status from taking a selfie with an object that is not owned, or checking in social media as if he/ she is in the nice places that in fact is not actually visited), and other pleasures. This is in line with the principle of hedonic motivation that aims to seek enjoyment based on the process of seeking pleasure and giving special treatment to the self (as indicated 
from the questionnaire items). Hedonic individuals will not consider NHNF morally wrong.

However, NHNF may also result in self-disrespect due to the presence of moral signal (e.g., when using counterfeit items: "I am fake"; Gino, Norton, \& Ariely, 2010) sent from the conscience to the entire self of an individual, for example, when it is done acutely and intensely. In contrast to the explanation earlier, these hedonic individuals will see NHNF as morally wrong because it resulted in pain (guilty feeling) rather than pleasure, therefore making them question the moral value of the behavior. This is in line with neutralization theory (McGregor, 2008) that explained how most people are not immune to guilt and regret. This means that there is a phase where a consumer feels both emotions when doing behavior that is actually or potentially unethical, even when such realization usually gets followed up with neutralization in the form of "denial of injury", that underlies the concept of NHNF in this study, with expressions such as "It's no big deal. They have lots of money ... No one got hurt ... I didn't really hurt anyone ... the actions I take as one person are so small and insignificant that nobody is harmed ... I am just one person. What harm can I cause?" (McGregor, 2008). Despite its brief occurrence, the particular phase is still felt and becomes a significant part of a real psychological experience, and is reflected especially by people with ethical hedonism.

In particular, Tomer (2011) stated:

"Experiencing hedonic pleasure is only problematic if this aspect of life is out of balance with the eudaimonic aspect, and severe neglect of hedonic pleasure is generally not the right balance with the eudaimonic aspect. For high happiness, there needs to be some kind of balance between the hedonic and eudaimonic aspects of life" (p. 535).

Therefore, the dual nature of hedonic motivation (being capable of both supporting and rejecting the idea that NHNF is unethical), can help explain why the predictive correlation hypothesis in this study was not supported.

The lack of predictive correlation between hedonic motivation and NHNF may also be caused by the fact that items in the hedonic motivation scales were confined mostly to the context of shopping when not all individuals seem to like shopping. Thus, the measurement may not be sensitive enough in capturing general hedonic motivation or hedonic motivation in other (non-shopping) dimensions. NHNF consists of both shopping and non-shopping behavior, and as such this lack of sensitivity may result in the absence of predictive correlation.

Cornwell, Franks, and Higgins (2014) have also shown that hedonic motivation is not sufficient to be considered the only construct to explain complex human behavior. They stated that integrative responses to the questions of "what" (truth motivation), "how" (control motivation), and "why" (value motivation) regarding the behavior of approaching/avoiding outcomes (pleasure/pain) are needed to increase the predictive power of the knowledge of hedonic motivation of a person towards his/her actual behavior (in this case NHNF). Future studies are recommended to include an in-depth examination of such "what", "how", and "why" variables.

Results of this study also showed that higher utilitarian motivation contributes to the higher evaluation of NHNF unethicality (or considering that NHNF is morally wrong).

In the context of the five items in NHNF measurement used in this study (using tester products and trying on clothes without intending to buy, even returning a product if disappointed), no party (especially the seller/producer) was harmed. However, the negative emotions expressed by the sales promotion girl as described by the tester (e.g., the statement: "I don't try more than three testers because the salesperson girl looked rather unfriendly") in the field (Luvmyfm, 2015) can be perceived by the consumer as something that disturbs the wellbeing of others, in this case, the salesperson girl. Additionally, there is the possibility that sampling tester products may result in further financial losses (becoming persuaded to buy a more expensive item, like a stove, that is not actually needed, "tester as a disguised opener") or the negative experience of being "chased" by the salespeople (Amalia, 2010; Rin, 2014). These experiences result in highly utilitarian people perceiving NHNF as unethical because the final outcome is disadvantageous for themselves and other people. This is in contrast to the utilitarian principle of "the greatest good for the greatest number".

Another explanation can be obtained by examining the utilitarian motivation measurement items, such as "On a particular shopping trip, it is important to find items I am looking for", and "It is disappointing when I have to go to multiple stores to complete my shopping." These items pointed out the priority of efficiency, practicality, and effectiveness, as well as functionality and goal dependence of shopping. Based on some empirical findings, these cognitive 
priorities are associated with self-regulation through directed attention modality (Kaplan \& Berman, 2010) and, on an affective dimension, utilitarian motivation is indeed associated with emotional regulation (Lee \& Gino, 2015). By having a perception of "utility" in mind, a person will be guided by his/her cognition to be involved in useful-albeit unpleasurablebehavior, and sometimes they often have to engage in delaying instant gratification for future distant goal or utility (Tamir, Chiu, \& Gross, 2007). Evidence lends support to the idea that such self-regulation is correlated with ethical decision making. This is because self-regulation encompasses self-control that systematically copes with egocentric drive or self-interest, focusing on virtuous actions, reflecting long-term considerations, and self-monitoring, including the ability to provide reward and punishment for his/her own behavior; these qualities motivate attachment to moral standards (Joosten, van Dijke, Van Hiel, \& De Cremer, 2014; Sekerka, McCabe, \& Bagozzi, 2014; Woods \& Lamond, 2011).

Indonesian society is a collectivist society, caring towards the in-group, and having a "we" instead of "I" self-concept (The Hofstede Center, 2015). Chowdhury and Fernando (2013) showed through their empirical research that communal well-being has a positive correlation with NHNF. It was explained that this is because, in certain contexts, NHNF can be beneficial to others, such as burning some duplicate CDs, recording and sharing a live concert, or copying and activating licensed computer software for those who are unable to purchase the license. This desire to benefit many other people is related to utilitarian motivation described earlier. This assumption is linked with the standard of the utility: "the greatest good for the greatest number" (Knapp \& VandeCreek, 2006) that is in line with the Indonesian cultural orientation (The Hofstede Centre, 2015). One item from the utilitarian motivation scale is "I like to feel smart about my shopping trip". One of the main considerations in smart shopping in a communal-collectivist environment is shopping that benefits other in-group members (Aggarwal, 2004), such as group buying that allows everyone in the group to get a special price (Dameyasani \& Abraham, 2013). The predictive correlation between utilitarian motivation - influenced by collectivism - and NHNF is also in line with the empirical research done by Hendriana, Mayasari, and Gunadi (2013) who found that Indonesians justify counterfeit product using behavior (an example of NHNF) based on the assumption "that everyone should get the benefit from a new invention".
In accordance with the explanation above, utilitarianism should negatively predict consideration of NHNF unethicality. However, the current study found that utilitarian motivation has a positive prediction on NHNF unethicality.

Based on the finding of this present study, the author did a further examination on the NHNF measurement. There are at least six out of 15 NHNF items that can potentially be beneficial for a collective, which are: (1) 'Burning' a CD rather than buying it; (2) Recording a movie off the television; (3) Installing software on your computer without buying it; (4) Making a video recording of a live concert and sharing it to others; (5) Purchasing counterfeit products instead of original ones; and (6) Downloading music from the internet without buying the original. However, the last item was eliminated in the process of validating the measurement, so only five items were left. Despite the saying that Indonesians "cannot truly accept the concept of intellectual property rights" (Hendriana et al., 2013), in this case supporting piracy and counterfeit product using in the collectivism context, the term collectivism need to be examined by content and situation. Collectivism is often insufficiently understood as merely prioritizing the needs of a group while ignoring the norms developing within the group. As an example, even though the concept of intellectual property is absent in the psychological reality of Chinese people, but the norm of "Guanxi" (social interconnectedness in personal and business relationships), stating that "A strong sense (unspoken convention) within guanxi wang's that using or purchasing pirated software is bad ... [and] detrimental to the collective society" and results in losing face (shamed) when performed (Simmons \& Tan, 2002), has functioned as a social and personal control for the Chinese people.

In relations to the findings of this present study, the participants were university students $(94 \%)$ and high school students (6\%) who are considered as educated individuals, where it is possible that, as a result of their education, their sense of collectivism has been influenced by the appreciation of the creation and efforts of others. For example, compared to their non-scholar peers, these students have been trained to give credit to the contribution of others through scientific writing, by correctly making citations and references. This could cause utilitarianists who spend a majority of their time in universities and schools to perceive NHNF behavior as unethical. This is in line with the study by Olivia, Tong, and Wong (2012) who found that level of 
education has a positive moderation effect on consumer ethics. The university students may indeed be tempted to engage in risky behavior, as explained earlier in the discussion regarding hedonic motivation, but it seems that this temptation is overridden by collectivist norms giving away a salient imagination regarding the existence of intellectual peers and artists that will be victimized by piracy and counterfeiting. This also explains the lack of predictive correlation between hedonic motivation and evaluation of NHNF unethicality, and the positive predictive correlation between utilitarian motivation and evaluation of NHNF unethicality.

Moreover, nine items (majority) of the NHNF are closely related to, firstly, "experimentation" of a product without the intention to buy, or returning a product after purchase, and, secondly, engaging in deception and exploiting the lack of awareness of other people to acquire social status for the self.

The logic of collectivism that is integrated with utilitarianism actually did not match the psychological reality of participants in this study. It is possible that collectivists tend to accept ethical standards willingly, and their consumption activities are more about "socially responsible consumption" (Culiberg, 2015) - a part of smart shopping - that take consideration of other people. Some items of the NHNF questionnaire are clearly not directed towards that kind of consumption due to their "experimental" nature.

Researchers of utilitarianism have explained that the mindset of utilitarianism ("positive philosophy") is essentially in line with the soul of positive psychology because utilitarianism was historically created in the golden age of peace, wellbeing, and prosperity of countries in the world (Guha \& Carson, 2014; Pawelski \& Maya, 2009). On an individual level, the majority of NHNF examples in the questionnaire items, as shown in this Discussion section, clearly did not support the positive qualities of life, and instead could cause disruptions to the wellbeing of the self (feeling of social irresponsibility) and other people (creating negative emotion on others). These conditions cause those with utilitarian motivation to consider NHNF as morally wrong. This finding also highlights the positive side of utilitarianism, while keeping in mind the negative side - which are: (1) prioritizing consequences without considering the process; and (2) it is not always clear which party needs to be taken into consideration in the effort to understand the efficiency and effectiveness from the consequences of a utilitarian-motivated behavior.

\section{Limitations and Directions for Future Studies}

Limitations of the current study include the finding that the NHNF measurement used here is yet to be fully capable of distinguishing different forms of NHNF. As seen in the Discussion section, some types of NHNF are done routinely, while others are done incidentally; some NHNF may be done in the context of living with other people (e.g., duplicating music or computer software CDs and sharing them with others), while some may only be relevant for a single individual (e.g., sampling a tester cake); some NHNF were done in the direct presence of others (e.g., sales, when testing cosmetic product samples), and there are NHNFs done without direct contact with others (e.g., downloading music from the internet for free); there are NHNF perceived to have positive and negative consequences (depending on the cultural orientation), and there are intentional and unintentional NHNF (see below). Therefore, future research is suggested to develop and validate NHNF measurements through a factor analysis to better differentiate the varying types of NHNF. Improved measurements will bring to better interpretations over the presence of a correlation (or lack of), and will produce a useful recommendation of involving necessary moderating variables (such as level of education).

Based on the explanations in the Discussion, further studies are suggested to: (1) include ethical hedonism - the variable treated in the Discussion as an intervening variable - as a moderating variable; (2) consider the aspect of intensity as well as frequency of NHNF in the measurement; and (3) consider the compatibility of life domain between the predictor measurement and the criterion; ideally they should measure the same dimension or aspect, such as in shopping context, or general living. In addition, items for utilitarian motivation scale need to be improved so that they become more explicitly integrated with the aspect of collectivism that acts as a specific cultural orientation for Indonesians.

For the second suggestion, "intensity" is defined as an aspect that indicates the level of contribution an individual makes to the unethical NHNF. This can be illustrated by the following two NHNF events, as quoted from Berman (2011):

"Some evenings ago my wife and I returned home to find our house empty, but the front door 
unlocked. Our kids' babysitter had taken them to the park and had forgotten to lock up. My wife remarked upon it when he returned. 'Gosh,' he said embarrassedly. 'You're right. I just forgot. I'm really sorry.' 'Well, it's okay,' she assured him. "No harm, no foul."”

"One pregnant woman learns of the name that her pregnant sister (or sister-in-law) intends to give her baby if it is a boy. She then forms the intention to give it to her own baby, if a son, knowing that doing so would make the name no longer attractive, or significantly less attractive, to the couple who had the idea before her. That both women bore girls softens the sting of the betrayal, but the notion that the sister-in-law did nothing wrong, or that 'there's no problem' with her conduct, seems plainly mistaken. We are told, after all, that she 'stole' something (a name). That would seem to be wrongful if true. That the wrong proved harmless is fortunate, but not an erasure of the wrong itself."

From the two examples, the second example seems to have more intensity (quality of unethicality) in NHNF, because the actor clearly intended to commit the behavior; despite the fact that both examples yield the same result, that is, there was no harm done.

\section{Conclusion and Implications}

This present study concludes that from the two types of consumption motivation, only utilitarian motivation can predict the evaluation of NHNF unethicality, in a positive direction. Hedonic motivation cannot predict it.

The implication of this finding is that a healthy amount of utilitarian motivation in the world of consumption needs to be developed and nurtured if one intends to prevent NHNF. In the consumer world, utilitarian motivation will help consumers think through their decisions before committing to a behavior, preventing instant gratification and impulsivity (Russo, 2000), including NHNF. The consumer will consider all the potential consequences of NHNF, including the short-term and long-term consequences, and who will be affected by the action. The individual will even make necessary sacrifices to uphold "the greatest good for the greatest number" principle.

In real life, however, the application of utilitarianism needs to be balanced with education to prevent it from spreading to other fields other than consumption, especially when one needs to sacrifice minority group members or ignoring process to get the desired results. An undesirable example would be answering "Yes" to the following sacrificial dilemma:

"Your plane has crashed in the Himalayas. The only survivors are you, some other men, and a young boy. The six of you travel for days, battling extreme cold and wind. Your only chance of survival is to make it to a village a few days away. The boy cannot move very quickly. Without food, you and the other men will surely die. One of the men suggests killing the boy and eating his remains over the next few days. In this situation, would you sacrifice the boy?" (Bartels \& Pizarro, 2011, p. 159).

The issues brought up in the Discussion has expanded upon the traditional explanation regarding consumption motivation that is often limited on shopping services and facilities, price, comfort, and other related factors (e.g. Martínez-López, PlaGarcía, Gázquez-Abad, \& Rodríguez-Ardura, 2014). The present research highlighted the human aspect, in this case how consumption motivation can provide a richer and more fruitful discussion about the psychological dynamics of ethical behavior, in particular, NHNF.

\section{References}

Adomaviciute, K. (2013). Relationship between utilitarian and hedonic consumer behavior and socially responsible consumption. Economics and Management, 18(4), 754-760.

Agerström, J., \& Björklund, F. (2013). Temporal construal and moral motivation. In K. Heinrichs, F. Oser, \& T. Lovat (Eds.), Handbook of moral motivation: Theories, models, applications (pp. 181-194). Rotterdam: Sense Publishers. http://dx. doi.org/10.1007/978-94-6209-275-4_11

Aggarwal, P. (2004). The effects of brand relationship norms on consumer attitudes and behavior. Journal of Consumer Research, 31, 87101. http://dx.doi.org/10.1086/ 383426

Amalia, R. R. (2010, July 8). We try, and we (NOT) buy. Retrieved from https://mitliven.wordpress. com/2010/08/07/we-try-and-we-not-buy/

Arli, D., Tjiptono, F., \& Winit, W. (2015). Consumer ethics among young consumers in developing countries: A cross national study. 
Social Responsibility Journal, 11(3), 449-466. http://dx.doi.org/10.1108/SRJ-05-2013-0059

Bandura, A. (1986). Social foundations of thought and action: A social cognitive theory. Englewood Cliffs, NJ: Prentice Hall.

Bandura, A. (1990). Selective activation and disengagement of moral control. Journal of Social Issues, 46, 27-46. http://dx.doi.org/10.1111/j.154 0-4560.1990.tb00270.x

Bartels, D. M., \& Pizarro, D. A. (2011). The mismeasure of morals: Antisocial personality traits predict utilitarian responses to moral dilemmas. Cognition, 121, 154-161. http://dx.doi.org/10. 1016/j.cognition.2011. 05.010

Berg-Cross, L. G. (1975). Intentionality, degree of damage, and moral judgments. Child Development, 46(4), 970-974. http://dx.doi.org/10.2307/ 1128406

Berman, M. N. (2011). "Let "em play": A study in the jurisprudence of sport. Georgetown Law Journal, 99(5), 1325-1369. Retrieved from http://george townlawjournal.org/files/pdf/99-5/Berman .PDF

Bertens, K. (2001). Etika. Jakarta: Gramedia Pustaka Utama.

Callen, K. S., \& Ownbey, S. F. (2003). Associations between demographics and perceptions of unethical consumer behaviour. International Journal of Consumer Studies, 27, 99-110. http:// dx.doi.org/10.1046/j.1470-64 31.2003.00289.x

Childers, T. L., Carr, C. L., Peck, J., \& Carson, S. (2001). Hedonic and utilitarian motivations for online retail shopping behavior. Journal of Retailing, 77, 511-535. http:// dx.doi.org/10.1016 /S0022-4359(01)00056-2

Chiou, J-S., \& Pan, L-Y. (2007). The impact of Social Darwinism perception, status anxiety, perceived trust of people, and cultural orientation on consumer ethical beliefs. Journal of Business Ethics, 78, 487-502. http://dx.doi.org/10.1007/ s10551-007-9364-x

Chowdhury, R. M. M. I., \& Fernando, M. (2013). The role of spiritual well-being and materialism in determining consumers' ethical beliefs: An empirical study with Australian consumers. Journal of Business Ethics, 113, 61-79. http:// dx.doi.org/10.1007/s10551-012-1282-x

Chowdhury, R. M. M. I., \& Fernando, M. (2014). The relationships of empathy, moral identity and cynicism with consumers' ethical beliefs: The mediating role of moral disengagement. Journal of Business Ethics, 124, 677-694. http://dx.doi. org/10.1007/s10551-013-1896-7
Cornwell, J. F. M., Franks, B., \& Higgins, E. T. (2014). Truth, control, and value motivations: The "what," "how," and "why" of approach and avoidance. Frontiers in Systems Neuroscience, 7, 194.http://dx.doi.org/10.3389\% 2Ffnsys.2014.00194

Culiberg, B. (2015). The role of moral philosophies and value orientations in consumer ethics: A post-transitional European country perspective. Journal of Consumer Policy, 38, 211-228. http://dx.doi.org/10.1007/s10603-015-9295-3

Dameyasani, A. W., \& Abraham, J. (2013). Impulsive buying, cultural values dimensions, and symbolic meaning of money: A study on college students in Indonesia's capital city and its surrounding. International Journal of Research Studies in Psychology, 2(4), 35-52. http://dx.doi. org/10.5861/ijrsp.2013.374

de Bock, T., \& van Kenhove, P. (2010). Consumer ethics: The role of self-regulatory focus. Journal of Business Ethics, 97, 241-255. http://dx.doi.org/ 10.1007/s10551-010-0507-0

DeLeon, P. (2015). Thinking about political corruption. New York: Taylor and Francis.

Dijkstra, J. K., Kretschmer, T., Lindenberg, S., \& Veenstra, R. (2015). Hedonic, instrumental, and normative motives: Differentiating patterns for popular, accepted, and rejected adolescents. Journal of Early Adolescence, 35(3), 308-328. http://dx.doi.org/10.1177/02724 31614535092

Ding, C. G., Chang, K., \& Liu, N-T. (2009). The roles of personality and general ethical judgments in intention to not repay credit card expenses. The Service Industries Journal, 29(6), 813-834. http ://dx.doi.org/10.1080/026420 60902749369

Egan, V., \& Taylor, D. (2010). Shoplifting, unethical consumer behaviour, and personality. Personality and Individual Differences, 48, 878-883. http://dx. doi.org/10.1016/j. paid.2010.02.014

Gino, F., Moore, D. A., \& Bazerman, M. H. (2009). No harm, no foul: The outcome bias in ethical judgments. Retrieved from http://www.hbs.edu/ research/pdf/08-080.pdf

Gino, F., Norton, M. I., \& Ariely, D. (2010). The counterfeit self: The deceptive costs of faking it. Psychological Science, 21(5), 712-720. http://dx. doi.org/10.1177/0956797610366545

Gino, F., Shu, L. L., \& Bazerman, M. H. (2010). Nameless + harmless = blameless: When seemingly irrelevant factors influence judgment of (un)ethical behavior. Organizational Behavior and Human Decision Processes, 111, 93-101. http://dx.doi.org/10.1016/j.obhdp. 2009.11.001 
Graf, R. G. (1971). Induced self-esteem as a determinant of behavior. The Journal of Social Psychology, 85, 213-217

Guha, M., \& Carson, J. (2014). Positive psychology, utilitarianism and the pursuit of happiness. Journal of Mental Health, 23(4), 159-161. http:// dx.doi.org/10.3109/0 9638237.2014.928404

Hendriana, E., Mayasari, A. P., \& Gunadi, W. (2013). Why do college students buy counterfeit movies? International Journal of e-Education, $e$ Business, e-Management and e-Learning, 3(1), 6267. http://dx.doi.org/10.7763/IJEEEE.2013. V3.194

Higgins, E. T. (1997). Beyond pleasure and pain. American Psychologist, 52(12), 1280-1300.

Huang, C-C., Lu, L-C., You, C-S., \& Yen, S-W. (2012). The impacts of ethical ideology, materialism, and selected demographics on consumer ethics: An empirical study in china. Ethics \& Behavior, 22(4), 315-331. http://dx.doi.org/10. 1080/10508422.2012.677627

Jennifer. (2014). The invention of lying: Practice uncommon honesty. Retrieved from http://www. selfcreation.com/how-to-be-happy/practice-uncommon -honesty.htm

Jonsson, P. O. (2011). On utilitarianism vs virtue ethics as foundations of economic choice theory. Humanomics, 27(1), 24-40. http://dx.doi.org/10. 1108/08288661111110150

Joosten, A., van Dijke, M., Van Hiel, A., \& De Cremer, D. (2014). Being "in control" may make you lose control: The role of self-regulation in unethical leadership behavior. Journal of Business Ethics, 121, 1-14. http://dx.doi.org/10.1007/ s10551-013-1686-2

Kandrack, R., \& Lundberg, G. (2013). On the influence of emotion on decision making: The case of charitable giving. In P. Guo \& W. Pedrycz (Eds.), Human-centric decision-making models for social sciences (pp. 57-73). Berlin: Springer Verlag. http://dx.doi.org/10.1007/978-3642-39307-5_3

Kaplan, S., \& Berman, M. G. (2010). Directed attention as a common resource for executive functioning and self-regulation. Perspectives on Psychological Science, 5(1), 43-57. http:// dx.doi. org/10.1177/1745691609356784

Kavak, B., Gürel, E., \& Eryigit, C. (2009). Examining the effects of moral development level, self-concept, and self-monitoring on consumers' ethical attitudes. Journal of Business Ethics, 88(1), 115-135. http://dx.doi.org/10.1007/s10551-009-0114-0
Khafifah, N. (2015, May 30). Fadli Zon sebut korupsi jadi 'oli' pembangunan, pakar UGM: Logikanya keliru. DetikCom. Retrieved from http://news. detik.com/berita/2929660/fadli-zon-sebutkorupsijadi-oli-pembangunan-pakar-ugm-logikanya-keliru

Kim, H. S. (2006). Using hedonic and utilitarian shopping motivations to profile inner city consumers. Journal of Shopping Center Research, 13(1), 57-79.

Knapp, S. J., \& VandeCreek, L. D. (2006). Foundations of ethical behavior. In S. J. Knapp \& L. D. VandeCreek (Eds.), Practical ethics for psychologists: A positive approach (pp. 15-29). Washington, DC, US: American Psychological Association. http://dx.doi.org/10.1037/11331-002

Lee, J. J., \& Gino, F. (2015). Poker-faced morality: Concealing emotions leads to utilitarian decision making. Organizational Behavior and Human Decision Processes, 126, 49-64. http://dx.doi.org/ 10.1016/j.obhdp.2014.10.006

Liu, Z., Zeng, F., \& Su, C. (2009). Does relationship quality matter in consumer ethical decision making? Evidence from China. Journal of Business Ethics, 88, 483-496. http://dx.doi.org/10.1007/ s10551-009-0301-z

Loewenstein, G., Small, D., \& Strnad, J. (2006). Statistical, identifiable and iconic victims. In E. J. McCaffery \& J. Slemrod (Eds.), Behavioral public finance (pp. 32-46). New York: Russell Sage Foundation Press.

Lu, L-C., \& Lu, C-J. (2009). Moral philosophy, materialism, and consumer ethics: An exploratory study in Indonesia. Journal of Business Ethics, 94, 193-210. http://dx.doi. org/10.1007/s1 0551-009-0256-0

Luvmyfm. (2015, April 24). Testimoni usaha parfum dari member. Retrieved from http://tokoparfumas lifm.com/blog/testimoni-usaha-parfum-dari-member/

Magnis-Suseno, F. (1987). Etika dasar: Masalahmasalah pokok filsafat moral. Yogyakarta: Kanisius.

Martin, N. M., \& Prince, D. (2009). No harm, no foul. Journal of Academic and Business Ethics, 1, 100-106.

McGregor, S. L. T. (2008). Conceptualizing immoral and unethical consumption using neu-tralization theory. Family and Consumer Sciences Research Journal, 36(3), 261-276. http://dx.doi.org/10. 1177/107772 7X07312190

Martínez-López, F. J., Pla-García, C., GázquezAbad, J. C., \& Rodríguez-Ardura, I. (2014). Utilitarian motivations in online consumption: Dimensional structure and scales. Electronic 
Commerce Research and Applications, 13, 188204. http://dx.doi.org/10.1016/ j.elerap.2014.02.002 Muncy, J. A., \& Vitell, S. J. (1992). Consumer ethics: An investigation of the ethical beliefs of the final consumer. Journal of Business Research, 24, 297-311.

Olivia, L. W. L., Tong, C., \& Wong, A. (2012). The impact of materialism on consumer ethics: An empirical study on adult students in Hong Kong. Journal of Management Research, 4(2), 51-87. http://dx.doi.org/10.5296/jmr.v4 i2.1233

Oser, F. (2013). Models of moral motivation. In K. Heinrichs, F. Oser, \& T. Lovat (Eds.), Handbook of moral motivation: Theories, models, applications (pp. 7-26). Rotterdam: Sense Publishers.

Palazon, M., \& Delgado-Ballester, E. (2013). Hedonic or utilitarian premiums: Does it matter? European Journal of Marketing, 47(8), 1256-1275. http://dx.doi.org/10.1108/03090561311324318

Pawelski, J. O., \& Maya C. G. (2009). Utilitarianism. In S. J. Lopez, (Ed.), The Encyclopedia of Positive Psychology. Blackwell Publishing. Blackwell Reference Online. Retrieved from http://www. blackwellreference.com /subscriber/uid=/tocnode ?id=g9781405161251_chunk_g97814051612512 3_ss1-1\#citation

Rachel, J. (2004). Filsafat moral. Yogyakarta: Kanisius.

Rawwas, M. Y. A. (1996). Consumer ethics: An empirical investigation of the ethical beliefs of Austrian consumers. Journal of Business Ethics, 15, 1009-1019. http://dx.doi.org/10.1007/BF00 705579

Rin, T. H. (2014, February 22). [Tips \& trick] cara mencoba sampel/tester make-up di swalayan tanpa risih. Retrieved from http://crispyauntie. blogspot.co.id/2014/02/tips-trick-cara-mencobasampel-tester.html

Russo, M. S. (2000). Utilitarianism in a nutshell (or why no one likes a consequentialist). Retrieved from http://www.sophia-project.org/uploads/1/3/ 9/5/13955288/russo_utilitarianism1.pdf

Sekerka, L. E., McCabe, D. B., \& Bagozzi, R. P. (2014). Self-regulation: The moral muscle in online ethical consumerism. Journal of Marketing Development and Competitiveness, 8(1), 9-20.

Shu, L. L., Gino, F., \& Bazerman, M. H. (2011). Dishonest deed, clear conscience: When cheating leads to moral disengagement and motivated forgetting. Personality and Social Psychology Bulletin, 37(3), 330-349. http://dx.doi.org/10.1177/ 0146167211398138
Sidgwick, H. (1981). The methods of ethics (7th ed.). Indianapolis: Hackett Publishing Company.

Simmons, L. C., \& Tan, B. R. (2002). Understanding software piracy in collectivistic countries. In R. Zwick \& T. Ping (Eds.), AP - Asia Pacific Advances in Consumer Research (Vol. 5, pp. 252-257). Valdosta, GA: Association for Consumer Research.

Steenhaut, S., \& van Kenhove, P. (2006a). An empirical investigation of the relationships among a consumer's personal values, ethical ideology and ethical beliefs. Journal of Business Ethics, 64(2), 137-155. http://dx.doi.org/10.1007/s10551-005-5 905-3

Steenhaut, S., \& van Kenhove, P. (2006b). The mediating role of anticipated guilt in consumers' ethical decision-making. Journal of Business Ethics, 69, 269-288. http://dx.doi.org/10.1007/ s10551006-9090-9

Tamir, M., Chiu, C-Y., \& Gross, J. J. (2007). Business or pleasure? Utilitarian versus hedonic considerations in emotion regulation. Emotion, 7(3), 546-554. http://dx.doi.org/10.1037/1528-35 42.7.3.546

The Hofstede Center. (2015). What about Indonesia? Retrieved from http://geert-hofstede.com/indonesia.html

Tomer, J. F. (2011). Enduring happiness: Integrating the hedonic and eudaimonic approaches. The Journal of Socio-economics, 40, 530-537. http://dx.doi.org/10.1016/j.socec .2011.04.003

Trachtman, L. E. (1985). Why tolerate the statistical victim? The Hastings Center Report, 15(1), 14. http://dx.doi.org/10.2307/3561911

Vitell S. J., Lumpkin, J. R., \& Rawwas, M. Y. A. (1991). Consumer ethics: An investigation of the ethical beliefs of elderly consumers. Journal of Business Ethics, 10, 365-375. http://dx.doi.org/ 10.1007/BF00383238

Vitell, S. J., \& Muncy, J. (2005). The Muncy-Vitell Consumer Ethics Scale: A modification and application. Journal of Business Ethics, 62, 267275. http://dx.doi.org/10.1007/ s10551-005-7058-9

Vitell, S. J., Singh, J. J., \& Paolillo, J. (2007). Consumers' ethical beliefs: The roles of money, religiosity and attitude toward business. Journal of Business Ethics, 73, 369-379. http://dx.doi. org/10.1007/ s10551-006-9212-4

Woods, P. R., \& Lamond, D. A. (2011). What would Confucius do? - Confucian ethics and selfregulation in management. Journal of Business Ethics, 102, 669-683. http://dx.doi.org/10.1007/ s10551-011-0838-5 
Workplace Bullying Institute. (2012, May 11). Bully apologists rally to excuse adolescent Romney.
Retrieved from https://www.workplacebullying. org/mitt/ 